\title{
Economic Assessment of GM Corn Use in the Philippines
}

\author{
Flor Alvarez ${ }^{1}$, Abraham Manalo ${ }^{2}$, Ramon Clarete ${ }^{1, *}$ \\ ${ }^{1}$ School of Economics, University of the Philippines Diliman, Quezon City, Philippines. \\ ${ }^{2}$ National College of Public Administration and Governance, University of the Philippines Diliman, Quezon City, Philippines.
}

How to cite this paper: Flor Alvarez, Abraham Manalo, Ramon Clarete. (2021) Economic Assessment of GM Corn Use in the Philippines. International Journal of the Science of Food and Agriculture, 5(1), 115-128.

DOI: $10.26855 /$ ijfsa.2021.03.016

Received: January 30, 2021

Accepted: February 26, 2021

Published: March 8, 2021

"Corresponding author: Ramon Clarete, School of Economics, University of the Philippines Diliman, Quezon City, Philippines.

Email: ramonclarete@econ.upd.edu.ph

\begin{abstract}
Genetically modified yellow corn has increasingly been used in the Philippines since 2002. In just a period of 17 years, the area planted increased to about 835 thousand hectares, increasing by an average of $31.24 \%$ per year. A third of all corn farmers in the Philippines or about 460 thousand families are planting GM corn. Total factor productivity growth in the corn industry of the country was estimated to be $11.45 \%$ higher due to GM corn adoption. All household income deciles gained from the technology. Total welfare gain from adopting GM corn as measured by the equivalent variation of income reached $\$ 189.4$ million or nearly a tenth of a percent of total household income. Not only was the gain positive for all household income deciles, it was also inclusive: lower household income deciles benefit from the GM technology more than richer households.
\end{abstract}

\section{Keywords}

Genetic Engineering, Total Factor Productivity, Computable General Equilibrium Model

\section{Introduction}

This paper assesses the economic value of the use of genetically modified (GM) corn in the Philippines in nearly two decades. Existing assessments of the adoption of GM crops use a computable general equilibrium (CGE) model but assumes some productivity growth attributable to the technology. In this research, two-step estimation approach was conducted. It estimates first the total factor productivity growth associated with the use of GM corn, then assesses its effects on the economy using a CGE model of the Philippine economy. Genetically modified yellow corn has increasingly been used in the Philippines since 2002. In just a period of 17 years, the area planted increased to about 835 thousand hectares, increasing by an average of $31.24 \%$ per year. A third of all corn farmers in the Philippines or about 460 thousand families are planting GM corn.

In the following section, the paper reviews the extent of GM corn adoption in the Philippines. The third section takes up the 2-step methodology for estimating the value of GM corn adoption. This is followed by a discussion of the results of the study. Concluding section of the paper sums up the paper's findings.

\section{GM Corn Use in the Philippines}

Genetic engineering has been used in the Philippines to address phytosanitary problems in yellow corn farming. When the technology was first introduced in commercial scale in 2003, the major issue was the Asian corn borer (ACB), a highly destructive pest which bores into the corn ear, attacks the tassels, and eats up parts of the plant, lowering yields. Farmers must spray pesticides to control the outbreak which increased cost and exposed farmers to health risk. It is estimated that the outbreak could account for up to $80 \%$ profit loss of corn farmers [1]. Weeds aggravate the problem. Left unchecked, they also reduce productivity, and likewise farmers spray herbicides continuously or apply more labor to control the problem. There are no estimates of the adverse health effect on farmers who spray the corn plant to kill 
the corn borer and control the weeds.

Bacillus thuringiensis (Bt) corn is the first generation of GM corn in the Philippines. It was introduced by multi-national seed growers in 2002 following the issuance by the Department of Agriculture of its regulations on the commercial propagation and importation of GM plants and plant products. Bt is a natural enemy of the corn borer, which gets killed upon ingesting the microbe. Bt corn has a foreign Bt gene inserted into its genome using microparticle bombardment of plant cells or agrobacterium tumefaciens-mediated plant transformation. The inserted Bt gene enables the plant to protect itself from corn borers increasing yields. Without need to spray pesticide against ACB, the acquired trait gives GM corn farmers higher profits.

Following the Bt corn event, another GM corn product was developed carrying an external gene enabling the plant to express what is essentially effective tolerance against weedicides and other herbicides. Subsequent improvements of genetic engineering in corn produced the GM corn with stacked events that combined both the insect-resistant and herbicide-tolerant capabilities of the corn plant.

Table 1. GM Corn Approved in the Philippines, as of October 2020

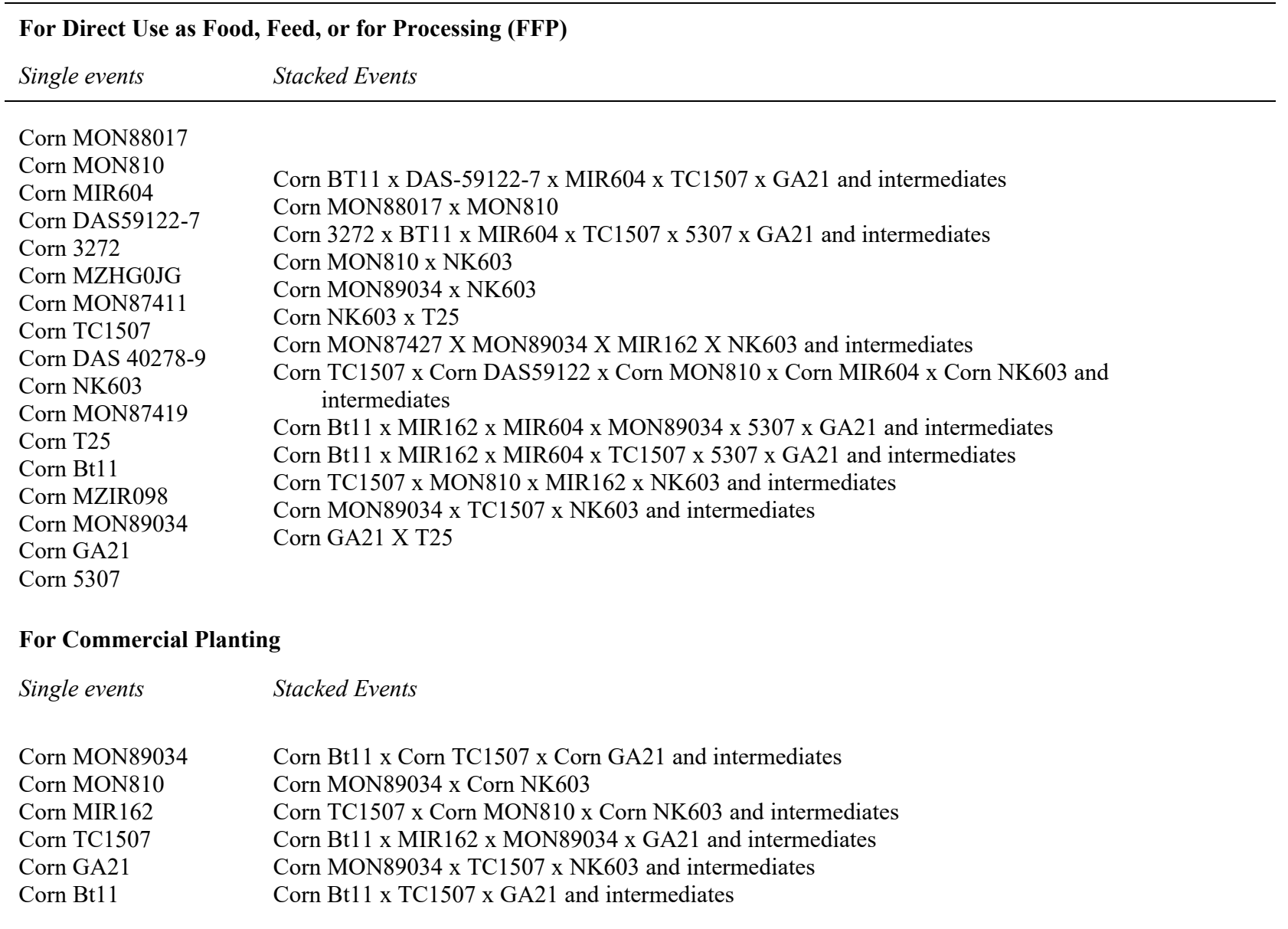

Source: Bureau of Plant Industry.

As of October 2020, there were 42 GM events in corn that have been approved by the Bureau of Plant Industry (BPI) of the Department of Agriculture. Of these approvals, 30 are for direct use as food, feed, or for processing (17 single events and 13 stacked events), while 12 are for commercial planting (6 single events and 6 stacked events) (Refer to Table 1). Generally, the GM corn events used in the Philippines address the problems of the corn borer infestation and the lack of tolerance of the corn plant to herbicides.

\subsection{Corn Sector}

Corn is the third largest crop of the Philippines in terms of area harvested next to rice and coconuts. In terms of value, it came in third after rice and bananas, on average, over the last decade. Furthermore, some 600,000 Filipino farm households depend on corn as a major source of livelihood [2]. 


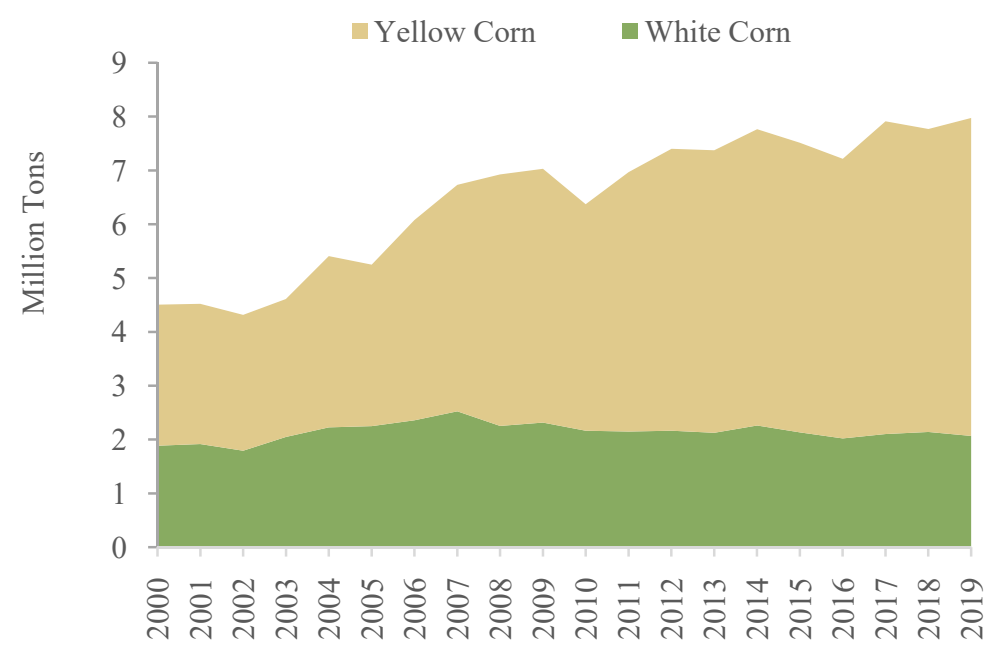

Source: Philippine Statistics Authority

Figure 1. Production, White and Yellow Corn, Philippines, 2000 to 2019.

The area harvested of corn reached 2.517 million hectares in 2019. Corn output has consistently grown through the years, except in few years when it declined due to extreme weather conditions. The country produced 4.5 million tons in 2000 and 8.0 million tons in 2019 (Figure 1).

In the same period, the average annual growth rate of corn production is 3.0\%. Yellow corn drives this growth, averaging 4.4\% per year compared to white corn's $0.5 \%$ from 2000 to 2019 . About three-fourths of the harvested corn is yellow corn, which accounts for approximately $50 \%$ of livestock mixed feeds. Meanwhile, white corn is mostly consumed as food by about 14 million Filipinos, although part of it is processed into industrial starch [3]. The share of white corn to total output has declined through the years. Its average share was $42.3 \%$ in 2000 to 2004 and $27.3 \%$ in 2015 to 2019.

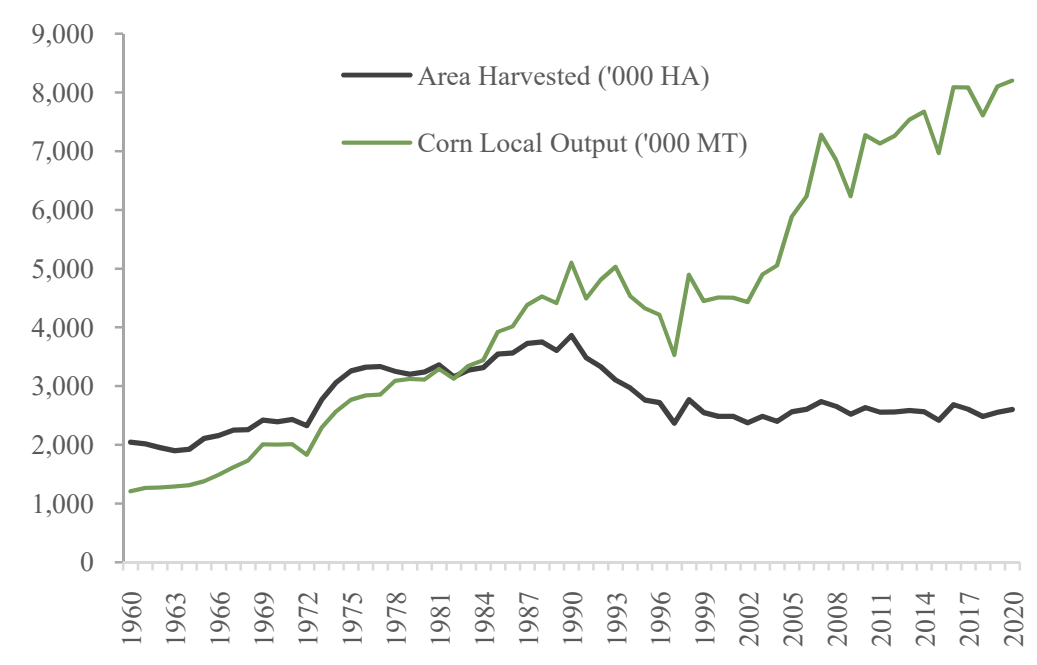

Source: MUNDI / US Department of Agriculture

Figure 2. Area Harvested and Production of Corn, the Philippines, 1960 to 2020.

Harvested corn area has declined since the middle of the 1980s, while corn production has increased (Figure 2). Despite the trend, local corn production has increased, indicating higher farm yields. This result is likely due to the adoption of yellow corn hybrids in the 1980s. The divergence between output and area harvested widened further since the 2000s, reflecting the introduction of GM yellow corn. 


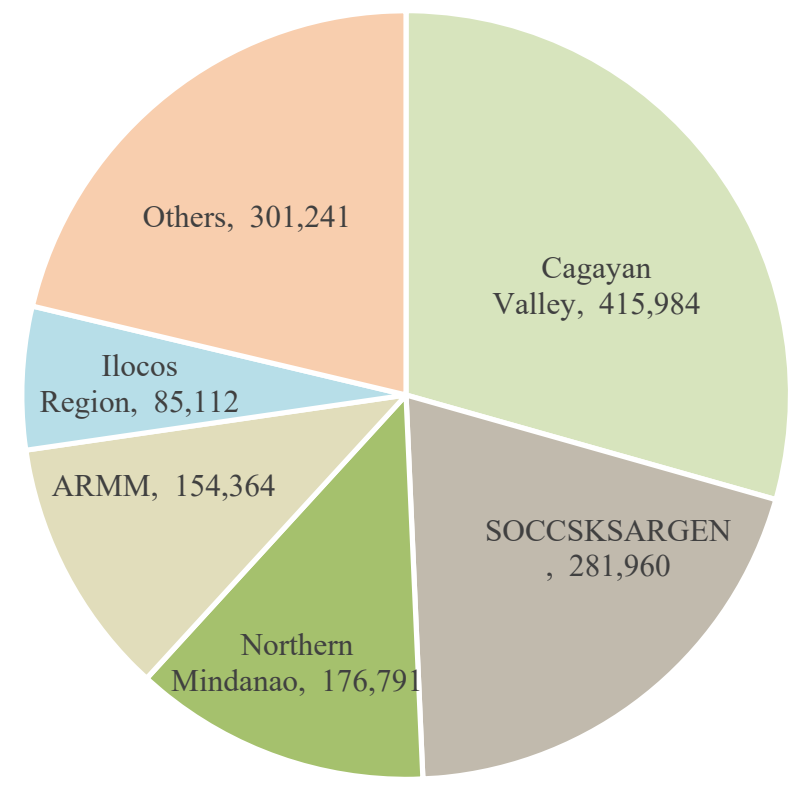

Source: Philipplne Stattstles Authority

Figure 3. Yellow Corn Area Harvested, Philippines, 2019.

Yellow corn was harvested from 1.415 million hectares in 2019 throughout the country. Not all the regions grow yellow corn in commercial quantity. The bulk of the yellow corn areas is in the Cagayan Valley, which accounts for $29.4 \%$ of total area planted to the commodity (Figure 3). SOCCSKSARGEN and Northern Mindanao are respectively the second (19.9\%) and third (12.5\%) largest yellow corn-producing regions. ARMM is fourth with $10.9 \%$ of total corn area, while Ilocos region is fifth with $6.0 \%$. The next largest regions in terms of area harvested with significant yellow corn production are the Western Visayas, Bicol, and the Cordillera Autonomous regions.

In terms of output, the five largest regions also topped in ranking following the same order. Combined, these five top-performing regions contributed to about $80 \%$ of total corn production in 2019 . The $20 \%$ balance comes from the remaining 11 regions in the country, excluding the highly urbanized Metro Manila or the National Capital Region.

The three largest regions also topped in ranking in terms of output. Although the Ilocos region and Central Luzon rank $5^{\text {th }}$ and $9^{\text {th }}$ respectively in terms of area, they had, however rank $4^{\text {th }}$ and $5^{\text {th }}$ in terms of output due to their relatively higher yields. On the other hand, Western Visayas, the Bicol region and CAR were a step lower in volume of yellow corn output.

The yellow corn areas in the country are located not where the bulk of the pig, chicken, and feed industries are located. These industries tend to be located near the areas where meats and eggs are in high demand. These products are bought everywhere in the Philippines but because of the relatively huge concentration of the market in the National Capital Region and the mega cities of Cebu, Bacolod and Iloilo, they tend to be mostly in Luzon and Visayas regions.

\subsection{GM Corn Adoption}

GM yellow corn has increasingly been used in the Philippines since its introduction. It was approved for commercial use in December 2002. A year later, the total area planted to GM corn was only 10,769 hectares, most of it in Cagayan Valley. Over a period of 17 years, the area planted increased to about 835 thousand hectares, increasing by an average of $31.24 \%$ per year (Figure 4). The adoption growth is relatively rapid despite the fact all that the Department of Agriculture did was to just to ensure a good regulatory regime for the safe use of GM corn in the country. The private sector seed owners marketed GM corn and conducted extension work to let the farmers know of the advantages of GM corn and facilitate the correct application of GM corn seeds.

All GM corn in the Philippines are yellow corn, accounting for two-thirds of all 1.415 million hectares planted to yellow corn as of 2019. With 2.517 million hectares planted to both yellow and white corn, GM corn accounts for nearly a third of the total corn farm area of the country in 2019, as shown in Figure 5. The average size of corn farms in the country is about 1.8 hectares and the number of corn farm households reach about 1.46 million. A third of corn farmers or about 460 thousand are planting GM corn. 


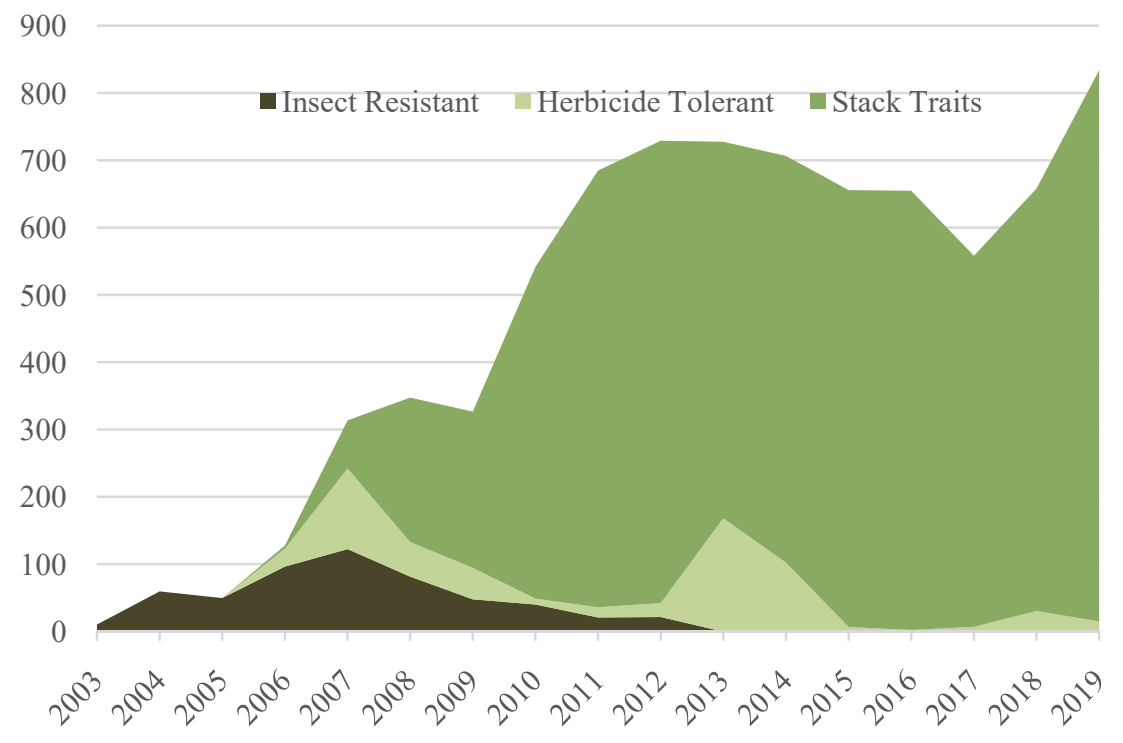

Source: Bureau of Plant Industry

Figure 4. Adoption of GM Corn in the Philippines, 2003 to 2019 (thousand hectares).

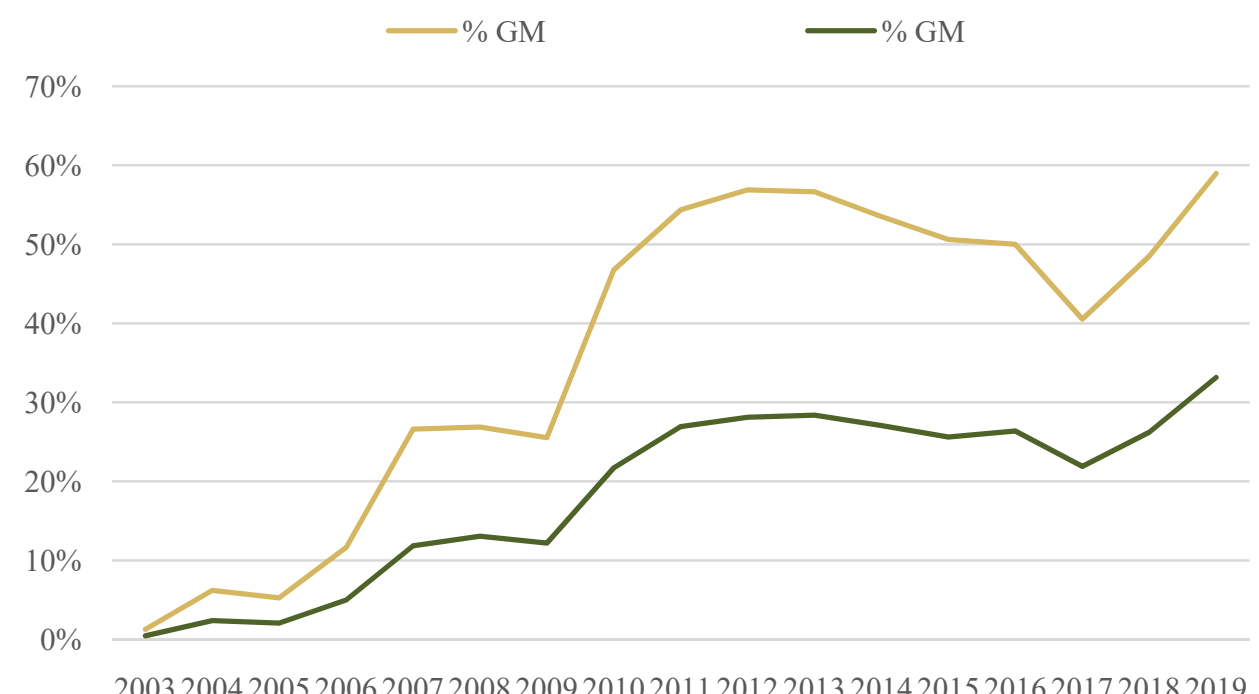

Source: Bureau of Plant Industry

Figure 5. Percent GM Corn to Yellow Corn and All Corn by Area, 2003 to 2019.

The introduction of the stacked traits GM corn accelerated significantly the adoption rate of the technology, as Figure 4 may show. About $80 \%$ of the area planted to GM corn is on the island of Luzon, followed by Mindanao with $12.2 \%$ of the total area.

The regional distribution of GM corn farms is shown in Table 2. In 2007, the insect resistant trait was dominant but gradually disappeared having been stacked into latter GM corn technology. Regions 1, 2, 10 and 12 accounted for $76 \%$ of all GM corn farms in 2007 and 74\% in 2019. The rest of Luzon has shown significant increase in the use of GM corn between the two years. In Mindanao, the total use in ARMM was only 5,764 hectares in 2007 and spiked to 21,004 hectares in 2019. Regions 7 and 8 have the lowest shares of GM corn in the country. 
Table 2. GM Corn Harvested Areas, By Regions, 2007 and 2019 (hectares)

\begin{tabular}{|c|c|c|c|c|c|c|c|}
\hline \multirow[b]{2}{*}{ Region } & \multicolumn{4}{|c|}{2007} & \multicolumn{3}{|c|}{2019} \\
\hline & $\begin{array}{l}\text { Insect Re- } \\
\text { sistant (IR) }\end{array}$ & $\begin{array}{c}\text { Herbicide } \\
\text { Tolerant }(\mathrm{HT})\end{array}$ & $\begin{array}{l}\text { Stacked (IR } \\
\text { and HT) }\end{array}$ & Total & $\begin{array}{c}\text { Herbicide } \\
\text { Tolerant }(\mathrm{HT})\end{array}$ & $\begin{array}{l}\text { Stacked(IR } \\
\text { and HT) }\end{array}$ & Total \\
\hline $\begin{array}{c}\text { Cordillera } \\
\text { Autonomous Region }\end{array}$ & 2,066 & 4,219 & 1,940 & 8,225 & 4,920 & 45,039 & 49,959 \\
\hline I & 38,017 & 68 & 1,314 & 39,399 & 570 & 89,125 & 89,695 \\
\hline II & 32,059 & 42,471 & 51,102 & 125,632 & 5,650 & 368,009 & 373,659 \\
\hline III & 19,481 & - & 1,589 & 21,070 & - & 34,529 & 34,529 \\
\hline IV-A & 80 & 45 & 350 & 475 & - & 4,164 & 4,164 \\
\hline IV-B & 8,003 & 135 & 760 & 8,898 & - & 19,703 & 19,703 \\
\hline V & 3,732 & 7,571 & 2,291 & 13,594 & 400 & 18,007 & 18,407 \\
\hline VI & 2,551 & 8,925 & 2,472 & 13,948 & 500 & 46,747 & 47,247 \\
\hline VII & - & - & - & - & - & - & - \\
\hline VIII & - & - & - & - & - & 272 & 272 \\
\hline IX & 363 & 401 & 152 & 916 & - & 6,030 & 6,030 \\
\hline$X$ & 3,018 & 23,871 & 1,802 & 28,691 & - & 91,403 & 91,403 \\
\hline XI & 34 & 382 & 160 & 576 & - & 5,104 & 5,104 \\
\hline XII & 10,643 & 28,015 & 5,425 & 44,083 & 2,550 & 58,264 & 60,814 \\
\hline XIII & 88 & 1,814 & 742 & 2,644 & - & 12,628 & 12,628 \\
\hline $\begin{array}{c}\text { Autonomous Region of } \\
\text { Muslim Mindanao }\end{array}$ & 2,478 & 2,106 & 1,180 & 5,764 & 730 & 20,274 & 21,004 \\
\hline Total & 122,613 & 120,023 & 71,279 & 313,915 & 15,320 & 819,297 & 834,617 \\
\hline
\end{tabular}

Source: Biotechnology Philippines, Bureau of Plant Industry.

\section{Estimating TFP Growth and Economic Effects of GM Corn}

The effect of GM corn adoption to regional corn productions and to the whole economy is estimated in this section. A two-step approach is used for this analysis. First, total factor productivity (TFP) growth of corn production with and without GM technology is estimated. The estimate is then inputted into a computable general equilibrium (CGE) model of the Philippine economy to assess its economic value.

Existing studies on the economic effect of GM technology make use of the CGE model [3, 4, 5, 7]. These authors make use of open economy CGE models in analyzing the impact of GM crop adoption. Most studies on GM adoption however use closed economy CGE models in regions such as China, United States, Europe and the African region.

Anderson and Yao [3] compare cases if China does and does not join GM crop adopters in the rice, cotton, maize and soybean sectors, separately and aggregately. They used the Global Trade Analysis Project (GTAP) model, a global multi-sector CGE model calibrated to replicate production, prices, employment, taxes and subsidies, trade policies, and bilateral trade flows. It describes both the vertical and horizontal linkages between all product markets and all countries through their bilateral trade flows. Technological change is brought into the model using a 5\% Hicks neutral productivity shift in the concerned sector/s. By adopting GM rice, China's welfare gain increases to $\$ 1.1$ billion which is approximately $55 \%$ of global gains. By adopting Bt cotton, China's welfare gain increases from $\$ 15$ million to $\$ 340$ million. By adopting GM maize and soybeans, all adopting regions gain modestly compared to adopting GM rice and Bt cotton. If China adopts all GM crops, it gains approximately $\$ 2.3$ billion.

Anderson, Jackson and Nielsen [4] extended the model to analyze not only the potential economic effects of adopting GM crop varieties but also their welfare and poverty alleviation implications in the Asian region. The GM crops increased farmer profitability and yields and/or fortified the commodity with nutrients such as golden rice which passed on Vitamin A to consumers. The GTAP model they used consisted of 17 regions and 14 sectors. Their result suggests larger income gains with nutrient-fortified crops than GM crops with traits for raising farm productivity. The authors explained that fortified GM crops have the added gain of boosting the productivity of unskilled workers who comprise 
most of Asia's poor.

On the other hand, Anderson, Jackson and Valenzuela [5] focused on the initial adoption of GM cotton and its economic impact on China, South Africa and other developing countries where it was common. A GTAP model with 27 sectors and 38 regions was employed in this case. Simulations are made with GM technology adoption with cotton subsidy and import tariff removals. Their findings suggest that income gains to second-adopting developing countries are larger than those which adopted first the technology like China and South Africa.

These studies on GM adoption overlooked the preference issue with GM crops, as Frisvold and Reeves [6] point out country restrictions to GM products. Gruère, Bouët and Mevel [7] attempted to account for the trade filter effect of GM technology on GM-sensitive countries such as those in the European Union, to allow the costly segregation of GM and non-GM crops, and to adopt a factor-biased productivity shock on heterogeneous types of land in Bangladesh, India, Indonesia and the Philippines. They argue that considering these improvements into the model will help in obtaining robust estimates of the economic effects of GM crops.

In the above studies, the improvement to productivity due to the use of GM technology is assumed. In contrast, this study first estimates the TFP growth using an econometric model before analyzing the economic implications of using the technology.

There had been attempts to estimate the TFP in the Philippines through the Solow growth accounting model [8]. Aba, Maglanoc and Garoy [9] compared Philippine growth patterns and TFP estimates with those of its ASEAN neighbors. Seriño and Seriño [10] investigated the performance of the Philippine agriculture from 1961 to 2005 using Solow growth accounting model. The theoretical model they used assumes that there exists a linear and homogeneous production function, a competitive equilibrium and neutral technical change. The Cobb-Douglas production function is used to estimate the weights of each factor input into the output. TFP growth is the Solow residual or that part of output growth that is unexplained by the expansion of production inputs.

The same model is adapted in estimating TFP to account for that part of it which is attributable to GM corn adoption. A GM technology identifier is introduced to the standard growth accounting model. The Solow residual is regarded as a composite of other factors (e.g. GM adoption rates and regional description of being a top producer of corn) which are incorporated in the estimation [8]. This will also allow for numerous simulations with different GM adoption rates across the data observations.

For the next step, unlike in Gruère, Bouët, and Mevel [7], the approach of this paper follows the following assumptions. First, GM corn is mainly for intermediate use removing the need for considering the trade filter effect. With this, costly segregation of GM and non-GM crops in corn industry is not necessary. Second, there is no need for assuming a factor-biased productivity shock as the estimating equation is able to disentangle the land qualities from its quantities in the micro model. It was already mentioned that the TFP estimate in this paper will include regional disparities in the Philippines. Since most GM corn varieties come from top-producing regions, TFP estimate on these regions is used.

It should also be noted that unlike previous studies on GM in CGE, this paper utilizes a small open economy CGE model instead of a GTAP model with multiple regions. This is convenient for CGE modelers in terms of computational effort and data gathering. As a small open economy, it is assumed that reforms within the country will not affect world economy at large unlike the previous cases with China and Africa among many others.

The following describes the two-step methodology in detail. The aim is to do a micro-macro synthesis that serves to examine how regional corn productions are improved with technological change and how this technological shock affect agents, other markets and macroeconomic indicators.

\subsection{Step One: TFP Estimation Model}

We use the TFP approach in order to capture technological effects to yield. Following the methods discussed [9, 10] above, the production function considered is

$$
Y_{k, t}=A_{k, t} F\left(L_{k, t}, N_{k, t}\right)
$$

where $Y_{k, t}$ is the volume of output of region $k$ in year $t$;

$A_{k, t}$ captures TFP of region $k$ in year $t$;

$L_{k, t}$ is the amount of labor inputs in region $k$ in year $t$; and

$N_{k, t}$ is the total arable land for corn production of region $k \mathrm{n}$ year $t$.

The growth in output can be decomposed into (2), and equation (3) gives us the TFP in year $t$.

$$
\begin{gathered}
\ln Y_{k, t}=\ln A_{k, t}+W_{L} \cdot \ln L_{k, t}+W_{N} \cdot \ln N_{k, t} \\
T F P_{k, t}=\ln A_{k, t}=\ln Y_{k, t}-W_{L} \cdot \ln L_{k, t}-W_{N} \cdot \ln N_{k, t}
\end{gathered}
$$

where $W_{L}$ and $W_{N}$ are weights for the growth of labor and capital respectively. Using linear squares regression, we estimate the following 


$$
\begin{aligned}
\ln Y_{k, t}= & \beta_{0}+\delta_{0} \text { top }+\delta_{1} \text { postGM }+\beta_{1} \text { GMrate }_{k, t}+\beta_{2}\left(\text { GMrate }_{k, t} \cdot \text { postGM }\right) \\
& +\beta_{3} \text { GMrate }_{k, t-1}+\beta_{4}\left(\text { GMrate }_{k, t-1} \cdot \operatorname{postGM}\right)+\beta_{5} \ln L_{k, t}+\beta_{6} \ln N_{k, t}+\varepsilon
\end{aligned}
$$

where GMrate $_{k, t-1}$ is the adoption rate of GM technology in year $t-1$;

postGM is the time dummy for years when GM technology was more densely adopted (from 2006-onwards); and

top is a dummy for top corn-producing region (namely, region I, II, X, XI, XII and ARMM).

The first seven terms including the constant term comprise the TFP growth estimates of region $k$ in year $t$. The regional dummy top captures the characteristics in top corn-producing regions that are unexplained by the amount of labor and land inputs for production. It may capture the qualities of these inputs such as human capital or knowledge on technological processes and soil compatibility on crops. The choice of years for postGM comes from the magnitude of GM adoption rate differential from 2005 to 2006. For regions in Luzon, the GM adoption rates have doubled on average (e.g. from $19.79 \%$ to $32.58 \%$ for region I; from $5.85 \%$ to $12.8 \%$ in region II). For the regions in Visayas and Mindanao, the adoption rates are not as high as in Luzon regions even though they more than doubled (e.g. from $0.41 \%$ to $4 \%$ in region VI; from $0.15 \%$ to $1 \%$ in ARMM). On a side note, the disparities in GM adoption rates among these island groups may have something to do with the dispersion of knowledge patterns. But apart from the 2006 boom in adoption rates, subsequent years display an increasing trend of GM adoption rates in all regions.

Additionally, the inclusion of lagged GM rates in the model has to do with the intuition that farmers and their yields may have been sensitive to the adoption of GM in prior years. For instance, farmers may be influenced by news from their fellow farmers who have already tried the new crop technology, or adopting GM may have improved land quality in previous years and increase yields in the current time period. The adoption rates in a preceding year is perceived to have a positive effect on contemporaneous adoption rate.

The regional corn data used from 2001 to 2018 were exclusively aggregated from the Philippine Statistics Authority (PSA) and the Department of Agriculture (DA) Bureau of Plant Industry (BPI) [11, 12, 13]. National Capital Region (NCR) was not included. Table 3 summarizes the variables in the model with their corresponding data descriptions. Meanwhile, Table 4 shows the summary of statistics. The model has 288 sample observations from 2001 to 2018.

\begin{tabular}{|c|c|c|c|c|c|}
\hline Variable & \multicolumn{4}{|c|}{ Data description } & Unit \\
\hline$Y_{k, t}$ & \multicolumn{4}{|c|}{ refers to the volume of production of corn in region $\mathrm{k}$ at time $\mathrm{t}$} & metric tons \\
\hline$L_{k, t}$ & \multicolumn{4}{|c|}{$\begin{array}{l}\text { refers to the amount labor inputs in region } \mathrm{k} \text { at time } \mathrm{t} \text {; } \\
\text { raw data from PSA is in mandays per hectare where it is computed as: } \\
\qquad \text { mandays of labor }=\frac{(\# \text { of workers }) *(\text { total hours of work })}{8 \text { hours }}\end{array}$} & mandays \\
\hline$N_{k, t}$ & \multicolumn{4}{|c|}{ refers to the area of land used in production of corn/area harvested in region $\mathrm{k}$ at time $\mathrm{t}$} & hectares \\
\hline GMrate $_{k, t}$ & \multicolumn{4}{|c|}{$\begin{array}{l}\text { refers to the GM technology adoption rate in region } \mathrm{k} \text { at time } \mathrm{t} \text {; } \\
\text { author computed as the ratio of GM corn adoption (in hectares) and total corn production area (in } \\
\text { hectares) times } 100\end{array}$} & percent \\
\hline \multicolumn{6}{|c|}{ Table 4. Summary of Statistics } \\
\hline Variable & Observations & Mean & Standard Deviation & Min & Max \\
\hline gmrate & 288 & 16.75191 & 24.88136 & 0 & 98.86 \\
\hline post_gmrate & 288 & 15.78545 & 25.10928 & 0 & 98.86 \\
\hline gmrate 1 & 288 & 15.70882 & 24.46527 & 0 & 94.92 \\
\hline post_gmrate1 & 288 & 15.21125 & 24.63181 & 0 & 94.92 \\
\hline ln_land & 288 & 11.59978 & 0.892992 & 10.04255 & 13.00616 \\
\hline ln_labor & 288 & 15.51036 & 0.9753748 & 13.19139 & 17.34651 \\
\hline ln_output & 288 & 12.41604 & 0.9882149 & 10.62884 & 14.44445 \\
\hline
\end{tabular}

Table 3. List of variables and their data description

\subsection{Step Two: CGE Model}

The CGE model used is calibrated to a 2015 Social Accounting Matrix (SAM) of the Philippines. A snapshot of the Philippine economy in 2015, the SAM is a square matrix summing up the central flows of payments and receipts by different economic actors in the year. The economy is described as comprising 50 sectors producing agricultural and 
non-agricultural goods and services. There are three primary factors namely low skilled labor, high skilled labor and capital; 10 representative households differentiated by incomes; and a government which collects taxes on trade, value added, and production.

The simulations use a standard, long-run neoclassical closure with perfect competition in all markets, flexible exchange rates and fixed endowments of all factor inputs. One should note that the model assumes that there is full employment. Trade sector is modelled using a nested Armington [14] structure which assumes that imported goods are qualitatively different but substitutable with locally produced products. Prices, wages and exchange rate are all initialized at 1 in the baseline year, defining appropriate units of each product. The simulations involve what-if exercises: (a) what if the total factor productivity growth in corn industry is zero in the absence of GM corn, and (b) what if such growth is positive as estimated in this study attributable to the use of GM corn. Changes in key economic variables are computed in the two scenarios and are attributed to GM corn use.

There are realistic features not captured by the model. It does not incorporate environmental or health externalities that groups oppose to GM use point out or on the other side the health benefits of reduced use of chemical pesticides to control the Asian corn borer. Although a scientific measurement of these externalities should be made, we abstract from these features.

The cost to owners of intellectual property rights of GM corn are also ignored in this study. Bayer, Norton and Falck-Zepeda [15] estimated the cost of compliance with biotechnology regulations at around \$1.7 million, while Manalo and Ramon [16] came up with the total cost of approximately $\$ 2.6$ million in 2004 prices inclusive of the cost of GM corn technology development. Although significant, these values are excluded. Development and compliance cost are assumed to have been incurred prior to commercialization way back in 2002, and as such are regarded as sunk costs. Whether the country adopts GM or not in its corn production, the costs have already been incurred and would not make a difference in the simulation results.

\section{Results and Discussion}

\subsection{Micro Regression}

Table 5 shows the summary of the regression results using ordinary and generalized least squares estimations. With ordinary least squares (OLS) regression, these results reveal that several coefficients of equation 4 were statistically insignificant: the lagged variables gmrate 1 and post_gmrate1. The TFP growth of top corn-producing regions is estimated to be approximately 0.53 higher than non-top corn-producing regions. This is expected as top regions' expertise in commercial production positively influence their productivity. When the GM technology was highly adopted in 2006, TFP in all regions increased by about 0.16 , on average, apart from the effect of marginal annual GM adoption rates. Generally, the effect of GM technology adoption in corn production should be interpreted with post_gm, gmrate, post_gmrate, gmrate1 and post_gmrate1.

Table 5. Summary of Regression Results: TFP Growth Estimates

\begin{tabular}{|c|c|c|c|c|}
\hline \multirow{2}{*}{$\begin{array}{c}\text { Dependent: } \text { ln_output } \\
\text { Independent }\end{array}$} & \multicolumn{2}{|c|}{ Pooled OLS (1) } & \multicolumn{2}{|c|}{ Random effects: GLS regression (2) } \\
\hline & Coefficient & Robust SE & Coefficient & $\mathrm{SE}$ \\
\hline \multicolumn{5}{|l|}{ TFP } \\
\hline Constant & 3.648167 & $0.4685942 * * *$ & 2.980093 & $0.6452254 * * *$ \\
\hline Top & 0.5348263 & $0.0679742 * * *$ & 0.5014016 & $0.1365278 * * *$ \\
\hline Post_gm & 0.1577938 & $0.0521513 * * *$ & 0.3093781 & $0.0238048 * * *$ \\
\hline Gmrate & 0.0324974 & $0.0084156^{* * *}$ & 0.0116697 & $0.0050641 * *$ \\
\hline Post_gmrate & -0.0277122 & $0.0084915^{* * *}$ & -0.0119357 & $0.0050926^{* *}$ \\
\hline Gmrate1 & -0.0055156 & 0.0125017 & 0.0005911 & 0.0079902 \\
\hline Post_gmrate1 & 0.011503 & 0.0125731 & 0.0017237 & 0.0080547 \\
\hline Ln_land & 1.068358 & $0.0868434 * * *$ & 1.101921 & $0.0708342 * * *$ \\
\hline Ln_labor & -0.2660078 & $0.0775875^{* * *}$ & -0.243899 & $0.0453025 * * *$ \\
\hline Observations & \multicolumn{2}{|c|}{288} & \multicolumn{2}{|c|}{288} \\
\hline (Overall) R-squared & \multicolumn{2}{|c|}{0.8993} & \multicolumn{2}{|c|}{0.8512} \\
\hline Root MSE & \multicolumn{2}{|c|}{0.31807} & & \\
\hline F-statistic & \multicolumn{2}{|c|}{$404.10 * * *$} & & \\
\hline Wald chi & & & \multicolumn{2}{|c|}{$1021.71 * * *$} \\
\hline
\end{tabular}

*** significant at $1 \%$ level; ** significant at 5\% level; * significant at $10 \%$ level. 
The coefficients of the control variables are consistent with past studies. The growth in land area allotted for corn production is positively significant as is expected from a production with Cobb-Douglas technology. On the other hand, the growth of labor inputs in corn production is negatively correlated with its output growth and is statistically significant at the 1\% level. Aba, Maglanoc and Garoy [9], using Solow Residual, also find labor elasticity to be negative. Another possible explanation may be the diminishing marginal productivity feature of labor in corn production. Miller and Upadhyay [17] explain how human capital decreases total factor productivity before a country's measure of openness passes some threshold level.

The estimated model observed heteroskedasticity, thus results are reported out in their robust form. Additionally, the model explains $89.93 \%$ of the variation in corn output growth. In subsequent analyses, the model can be improved to include more explanatory variables such as machineries, fertilizer and insecticide usage when data become available.

An alternative estimation method was also accomplished: the Generalized Least Squares (GLS). The Breusch-Pagan Lagrangian multiplier test for random effects says that we are better off estimating using random effects GLS ( prob $>\chi^{2}=0.00$ ) than pooled OLS, hence it is also reported in Table 5. The signs of the coefficients from the alternative method do not differ from the OLS regression except for gmratel which by the way remains statistically insignificant.

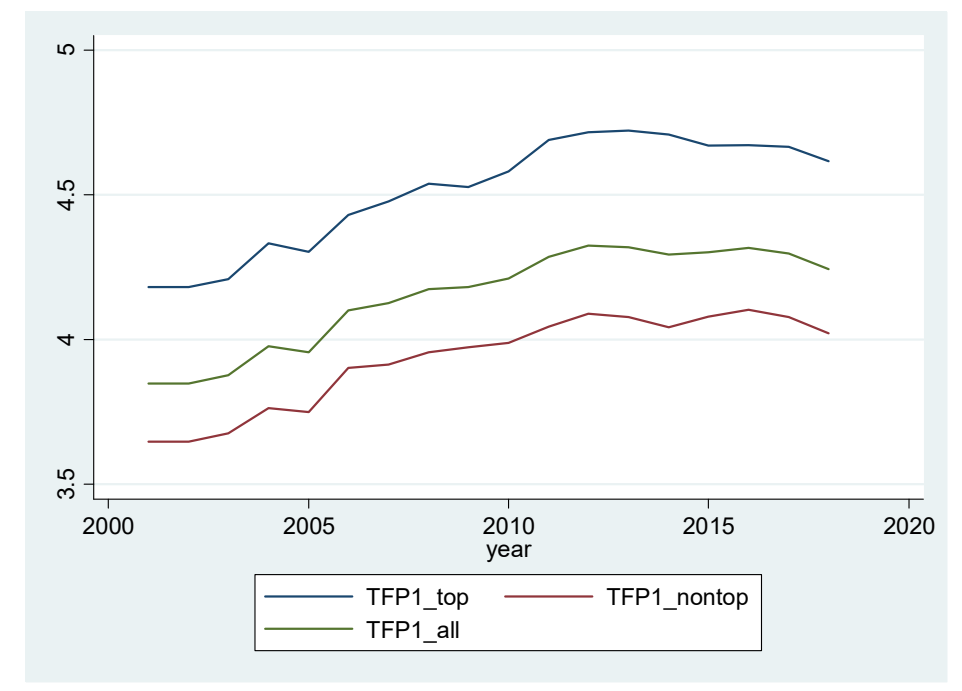

Figure 6. Estimated Mean TFP Using Pooled OLS from 2001 to 2018.

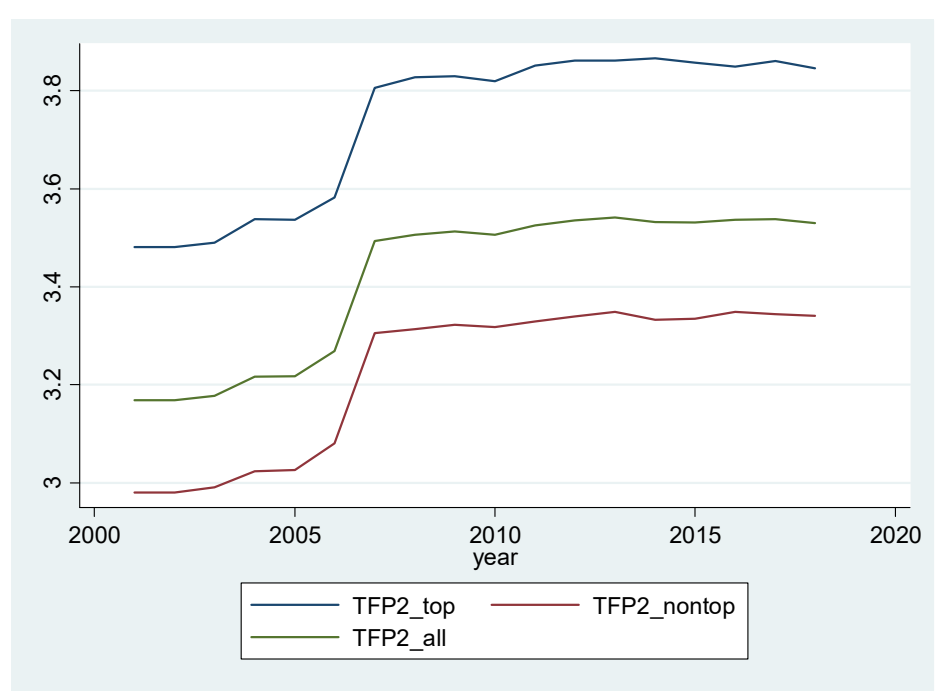

Figure 7. Estimated Mean TFP Using Random Effects GLS from 2001 to 2018.

Figures 6 and 7 show the estimated mean TFP paths using pooled OLS (TFP1) and random effects GLS (TFP2) from 2001 to 2018. Both models suggest that the estimated TFP of top and non-top corn-producing regions are all increasing from 2001 to 2018, on average, with a boom in 2006 as GM technology had begun to be adopted heavily. Additionally, 
as results are depicted in Figure 8, the adoption of GM technology in corn production in the Philippines is positive and significant.

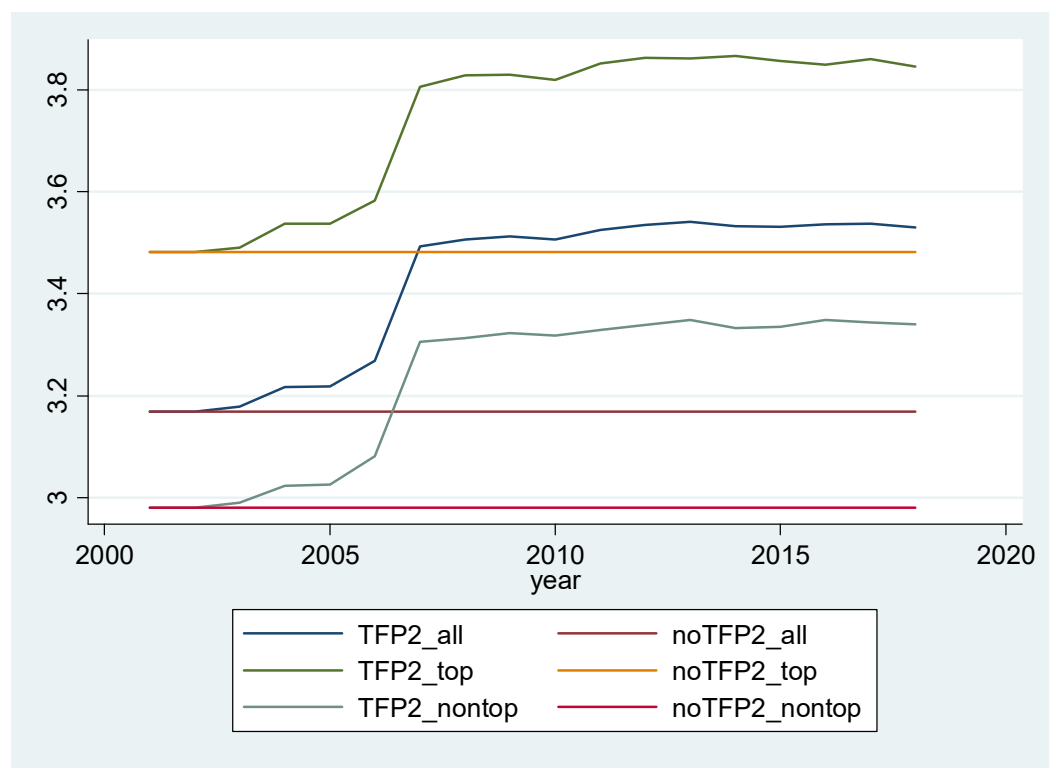

Figure 8. Comparison Between With and Without GM technology.

\subsection{CGE Simulation Results}

The random effects GLS TFP growth estimates are used in CGE simulations to evaluate the economic effects of adopting GM corn. With a 2015 Philippine SAM, a micro-macro analysis is conducted with and without GM corn adoption using the CGE model. Table 6 shows the estimates of TFP growth with and without GM corn. Without GM technology in 2015, top-producing regions would have $10.79 \%$ lower TFP growth than what they actually had as users of GM corn. Without GM technology in 2015, non-top-producing regions would have $11.91 \%$ lower TFP than what they actually had. On average, the economy is better off adopting the GM technology in 2015 as depicted by an approximate $11.45 \%$ higher TFP relative to benchmark.

Table 6. Comparing Total Factor Productivity With and Without GM technology in 2015

\begin{tabular}{ccccc}
\hline Group & Without & With & Difference & \% Change \\
\hline Top & 3.48 & 3.86 & 0.38 & 10.79 \\
Non-Top & 2.98 & 3.33 & 0.35 & 11.91 \\
Average (all) & 3.17 & 3.53 & 0.36 & 11.45 \\
\hline
\end{tabular}

The values in Table 6 illustrate the effects of GM technology adoption in a general equilibrium framework. In calibrating the model without GM corn, TFP in corn is set to 1. A counterfactual simulation is made such that GM technology is introduced into the system, particularly, feeding TFP ("corn") $=1.1079$ into the GAMS program. Notice that only top region TFP estimate is considered. The reason has to do with the underlying data in the SAM and the weight of these top regions in the corn production. The following discussion presents the CGE simulation results with and without GM corn adoption in the Philippines. Reports on the supply sector, price levels, income levels, tax collections, and macroeconomic indicators such as GDP, CPI and overall welfare are provided.

\subsubsection{Prices, Domestic Supply and Foreign Trade}

Table 7 shows the percentage changes in domestic production, foreign trade and prices relative to a no-GM-corn scenario. The CGE model was first solved as if the country did not adopt GM corn. Then the same model was recomputed for the GM scenario this time using the estimated induced TFP growth due to GM corn adoption using the average growth coefficient in Table 6 of $11.45 \%$. A hypothetical scenario was also computed under the assumption that all of the top corn-producing regions were adopting GM corn. The results from this counterfactual simulation are dubbed as 'GM100'.

Domestic corn production increased by a percent under the GM scenario relative to the no-GM baseline solution of the CGE model. In addition, the outputs of agriculture and non-agriculture sectors slightly increased as well with GM corn adoption, $0.17 \%$ and $0.10 \%$, respectively. 
Table 7. Changes in Domestic Production, Trade and Prices with GM Corn Adoption

\begin{tabular}{lllllll}
\hline \multirow{2}{*}{ Sector } & \multicolumn{2}{l}{ Production (\%) } & \multicolumn{2}{c}{ Imports/Exports (\%) } & \multicolumn{2}{c}{ Prices (\%) } \\
& $G M$ & $G M 100$ & $G M$ & $G M 100$ & $G M$ & $G M 100$ \\
\hline Corn & 1.00 & 1.40 & -5.60 & -7.40 & -6.50 & -8.60 \\
Agriculture & 0.17 & 0.19 & -0.05 & -0.05 & -0.23 & -0.29 \\
Non-agriculture & 0.10 & 0.13 & 0.09 & 0.13 & 0.00 & -0.01 \\
\hline
\end{tabular}

In terms of trade, corn imports decrease by $5.6 \%$ with GM corn adoption as domestic supply rises. Agricultural imports hardly fell, while those of non-agricultural sectors increased by a tenth of a percent. Meanwhile, the corn and aggregate agriculture industry experience significant dips of their price indices with GM technology. The price index of non-agricultural commodities is not affected.

The above changes are accentuated if all of the top corn-producing regions would have adopted GM corn. Corn output goes up by $1.4 \%$; corn imports fall by two percentage more compared to the GM scenario, $7.4 \%$; and corn prices dropped by over two percentage points more. Similar pattern is observed for the composite agriculture and non-agriculture sector.

\subsubsection{Income and Household Welfare}

Table 8 shows the changes in household income and welfare under the two scenarios. It can be observed that the GM corn delivered progressive income effects: lower household income deciles benefit from the GM technology by more than richer households, and the more so with the GM100 scenario. Meanwhile in terms of economic welfare (calculated using the equivalent variation of income), the middle class (HD3-HD8) benefit the most as depicted by 2-digit shares in increased welfare relative to the whole economy under GM and GM100. GM corn adoption appears to be inclusive.

Table 8. Changes in Household Income and Welfare with GM Corn Adoption

\begin{tabular}{cccccccccc}
\hline $\begin{array}{c}\text { Household } \\
\text { Decile }\end{array}$ & BASE & GM & \% Change & GM100 & $\%$ Change & GM & GM100 & GM Share (\%) & GM100 Share (\%) \\
\hline HD 1 & 299,544 & 299,807 & 0.09 & 299,892 & 0.12 & 416 & 550 & 4.6 & 4.6 \\
HD 2 & 540,400 & 540,852 & 0.08 & 540,997 & 0.11 & 777 & 1,029 & 8.5 & 8.5 \\
HD 3 & 717,659 & 718,211 & 0.08 & 718,388 & 0.10 & 987 & 1,307 & 10.9 & 10.9 \\
HD 4 & 844,999 & 845,610 & 0.07 & 845,807 & 0.10 & 1,059 & 1,402 & 11.6 & 11.6 \\
HD 5 & 919,891 & 920,486 & 0.06 & 920,677 & 0.09 & 962 & 1,274 & 10.6 & 10.6 \\
HD 6 & $1,012,824$ & $1,013,416$ & 0.06 & $1,013,607$ & 0.08 & 1,073 & 1,421 & 11.8 & 11.8 \\
HD 7 & $1,103,068$ & $1,103,594$ & 0.05 & $1,103,763$ & 0.06 & 1,044 & 1,382 & 11.5 & 11.5 \\
HD 8 & $1,195,563$ & $1,195,978$ & 0.03 & $1,196,110$ & 0.05 & 970 & 1,284 & 10.7 & 10.7 \\
HD 9 & $1,283,473$ & $1,283,689$ & 0.02 & $1,283,758$ & 0.02 & 764 & 1,011 & 8.4 & 8.4 \\
HD 10 & $1,977,434$ & $1,977,659$ & 0.01 & $1,977,730$ & 0.01 & 1,040 & 1,377 & 11.4 & 11.4 \\
\hline
\end{tabular}

*Equivalent Variation (EV) is used to compute for the household's welfare.

The total welfare gain of adopting GM corn is $\mathrm{PhP}$ 9,091 billion or nearly a tenth of a percent of the total household income in the base period of PhP 9.9 trillion. The gain measures how much households in the Philippines would willingly give up so that they are just as well off as if the Philippines did not adopt GM corn. The gain rises to 0.12 of a percent if hypothetically all top corn-producing regions of the country would have adopted GM corn.

\section{Concluding Remarks}

Several assessments of the economic value of GM crop adoption use a computable general equilibrium (CGE) model as in this paper but assume some productivity growth which they attribute to the technology. This paper takes a two-step assessment approach. First, total factor productivity (TFP) growth of corn production with and without GM technology is estimated. The TFP growth estimate is then inputted into a CGE model of the Philippine economy to assess its economic value.

The TFP growth estimation equation is adapted from Solow residual approach $[8,9,10]$. The final estimation equation comprises seven terms, namely the constant term, representing the average TFP growth estimate of all regions; regional dummy variable to capture the additional TFP growth in top corn-producing regions; the current and lagged GM 
adoption rates; time dummy variable to account for TFP growth expansion in latter years of the time series data; and interaction between the time dummy variable with current and lagged adoption rate. The inclusion of lagged GM rates in the model has to do with the intuition that farmers and their yields may have been sensitive to the adoption of GM in prior years.

Using pooled regional corn dataset from 2001 to 2018, the TFP estimation equation was estimated with significant coefficients for the TFP growth terms except for the two terms with lagged GM rates. Ordinary least squares and generalized least squares with random effects estimation methods were used. The estimates suggest that TFP growth in the corn industry of the country was $11.45 \%$ higher due to GM corn adoption.

The random effects GLS TFP growth estimates were used in CGE simulations to evaluate the economic effects of adopting GM corn. With a 2015 Philippine SAM, a micro-macro analysis is conducted with and without GM corn adoption using the CGE model. The model was solved with the use of GAMS.

Domestic corn production increased by a percent under the GM scenario relative to the no-GM baseline solution of the CGE model. In addition, the outputs of agriculture and non-agriculture sectors slightly increased as well with GM corn adoption, $0.17 \%$ and $0.10 \%$, respectively. In terms of trade, corn imports decrease by $5.4 \%$ with GM corn adoption as domestic supply rises.

The above changes are accentuated if all of the top corn-producing regions would have adopted GM corn. Corn output goes up by $1.4 \%$; corn imports fall by two percentage more compared to the GM scenario, $7.4 \%$; and corn prices drop by two percentage points more. Similar pattern is observed for the composite agriculture and non-agriculture sector.

All household income deciles gained from the technology. Total welfare gain from adopting GM corn as measured by the equivalent variation of income reached $\$ 189.4$ million or nearly a tenth of a percent of total household income. Not only was the gain positive for all household income deciles, it was also inclusive: lower household income deciles benefit from the GM technology more than richer households.

A few realistic features were not captured by the CGE model. It does not incorporate environmental or health externalities that groups oppose to GM use point out or on the other side the health benefits of reduced use of chemical pesticides to control the Asian corn borer. Although a scientific measurement of these externalities should be made, we abstract from these features. The cost to owners of intellectual property rights of GM corn are also ignored in this study.

\section{Acknowledgements}

The authors thank the Philippines Statistics Authority, especially Ms. Maria Carol G. Duran, for providing corn labor data, the Bureau of Plant Industry for GM corn adoption data, and the research team at the Ateneo de Manila University School of Government under a research contract with the Department of Trade and Industry/Board of Investments for the 2015 SAM and the original codes of the CGE model.

\section{References}

[1] Nafus, D. M. and Schreiner, I. H. (1991). Review of the Biology and Control of the Asian Corn Borer, Ostrinia Furnacalis (Lep: Pyralidae). Tropical Pest Management, 37(1), 41-56. https://doi.org/10.1080/09670879109371535.

[2] Department of Agriculture. (2020). Corn Program. http://rfo3.da.gov.ph/corn-program/.

[3] Anderson, K. and Yao, S. (2003). China, GMOs and World Trade in Agricultural and Textile Products. Pacific Economic Review, 8(2), 157-169. https://doi.org/10.1111/j.1468-0106.2002.00217.x.

[4] Anderson, K., Jackson, L. A., and Nielsen, C. P. (2005). Genetically Modified Rice Adoption: Implications for Welfare and Poverty Alleviation. Journal of Economic Integration, 20(4), 771-788. http://www.jstor.org/stable/23000670.

[5] Anderson, K., Valenzuela, E., and Jackson, L. A. (2006). GM Cotton Adoption, Recent and Prospective: A Global CGE Analysis of Economic Impacts. CEPR Discussion Papers, No. 5568.

[6] Frisvold, G. and Reeves, J. (2015). “Genetically Modified Crops: International Trade And Trade Policy Effects.” International Journal of Food and Agricultural Economics (IJFAEC), 3(2): 1-13. https://doi.org/10.22004/ag.econ.206302.

[7] Gruère, G., Bouët, A., and Mevel, S. (2007). Genetically Modified Food and International Trade: The case of India, Bangladesh, Indonesia and the Philippines. In 2007 Annual Meeting, July 29-August 1, 2007, Portland, Oregon, no. 9917. American Agricultural Economics Association (New Name 2008: Agricultural and Applied Economics Association).

[8] Solow, R. M. (1957). Technical Change and the Aggregate Production Function. The Review of Economics and Statistics, 312-320. http://www.jstor.org/stable/1926047.

[9] Aba, P., Maglanoc, D., and Garoy, E. (2016). Measuring Growth Residual: Empirical Evidence on Total Factor Productivity Test and Solow Growth Model. 13th National Convention on Statistics, Mandaluyong City, October 2016, 3-4.

[10] Seriño, M. N. V. and Seriño, E. K. L. (2016). Explaining Output Growth Using Total Factor Productivity: Evidence from the Philippine Agricultural Sector. Journal of Educational and Human Resource Development, 4, 108-118. 
[11] Biotechnology Philippines. (2019). IRM Monitoring. http://biotech.da.gov.ph/Irm.php.

[12] Philippine Statistic Authority. (2019). Palay and Corn: Area Harvested by Ecosystem/Croptype, by Quarter, by Semester, by Region and by Province, 1987-2019 by Ecosystem/Croptype, Geolocation, Year and Period. https:/openstat.psa.gov.

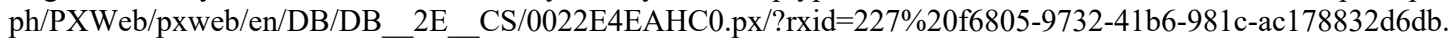

[13] Philippine Statistic Authority. (2019). Palay and Corn: Volume of Production by Ecosystem/Croptype, by Quarter, by Semester, by Region and by Province, 1987-2019 by Ecosystem/Croptype, Geolocation, Year and Period. https://openstat. psa.gov.ph/PXWeb/pxweb/en/DB/DB_2E_CS/0092E4ENVCP.px/?rxid=\%20227f6805-9732-41b6-981c-ac178832d6db.

[14] Armington, P. (1969). A Theory of Demand for Products Distinguished by Place of Production. IMF Econ Rev, 16, $159-178$. https://doi.org/10.2307/3866403.

[15] Bayer, J. C., Norton, G. W., and Falck-Zepeda, J. B. (2010). Cost of Compliance with Biotechnology Regulation in the Philippines: Implications for Developing Countries. AgBioForum, 13(1), 53-62.

[16] Manalo, A. J. and Ramon, G. P. (2007). The Cost of Product Development of Bt Corn Event MON810 in the Philippines. Agbioforum, 10(1), 19-32.

[17] Miller, S. M. and Upadhyay, M. P. (2000). The Effects of Openness, Trade Orientation, and Human Capital on Total Factor Productivity. Journal of development economics, 63(2), 399-423. https://doi.org/10.1016/S0304-3878(00)00112-7. 